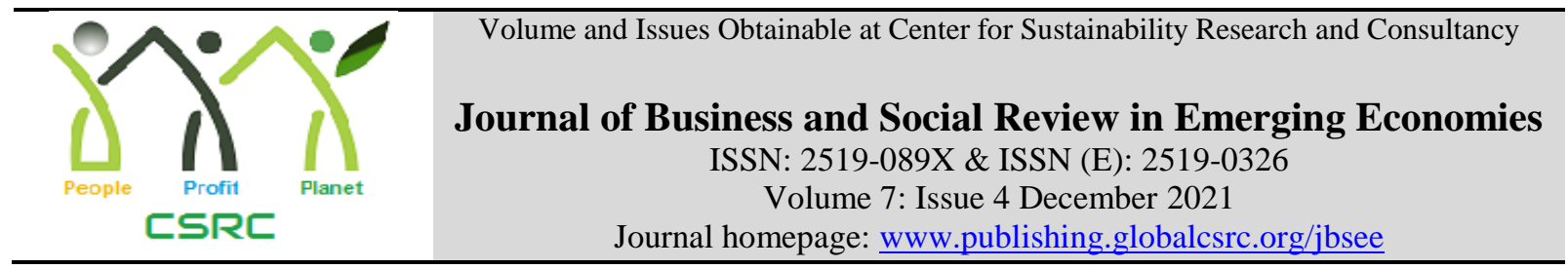

\title{
A Broader Relevance of Gullivers Suffering in the Context of Culture Shock
}

*Atteq ur Rahman, Islamia College Peshawar, Pakistan

Nadia Gul, Islamia College Peshawar, pakistan

Riaz Hussain, Islamia College Peshawar, Pakistan

*Corresponding author's email: atteq_h@hotmail.com

\begin{tabular}{l}
\hline ARTICLE DETAILS \\
\hline History \\
Revised format: Nov 2021 \\
Available Online: Dec 2021
\end{tabular}

Keywords

Culture shock, Identity

crisis, Sojourner, Hosts,

Diaspora, Migrants

JEL Classification

$M 1, M 2$

\section{OPEN ACCESS}

\section{ABSTRACT}

Purpose: This study analyzes Gulliver's sufferings among his different hosts and his relevancy to today's sojourners who travel abroad and suffer from the effects of culture shock. During his stay with four different hosts, Gulliver remains unable to adjust with them due to the impact of culture shock. He looks at his hosts from the cultural parameters of his native land that leads to multiplication his problems. Like him, most of the travelers who move abroad for various reasons undergo the effects of culture shock. If they fail to understand the internal and external aspects their hosts' culture, they may respond as Gulliver does.

Approach: Though critics have analyzed Gulliver's character from different perspectives, none has studied him from the lens of culture shock. On close analysis of the text of Gulliver's Travels, readers can easily observe Gulliver suffering from the effects of culture shock among his hosts. A fresh perspective has been adopted in this study by analyzing Gulliver's character in the light of culture shock. Culture shock affects sojourners in multiple ways. Many students, migrants, and the diaspora go through this experience while living in a new culture among new people.

Findings: This study shows that culture has been a common phenomenon for people who stay abroad for long or settle though they do not realize that several problems that they face are caused by culture shock. However, if someone consciously assimilates the effects of culture shock, it becomes a great experience to live a better life.

Implications: Though Gulliver belongs to the eighteenth century England, yet he exists around and among us. It is Gulliver's relevancy that adds to the meaningfulness of his character for the contemporary sojourners.

(C) 2021 The authors, under a Creative Commons AttributionNonCommercial 4.0

Recommended citation: Rahman, A., Gul, N. and Hussain, R. (2021). A Broader Relevance of Gullivers Suffering in the Context of Culture Shock. Journal of Business and Social Review in Emerging Economies, 7 (4), 909-916. 


\section{Introduction}

Gulliver's strange behavior among his hosts makes it evident that he remains unable to cope with the effects of culture shock. Since he looks at his hosts' culture from the cultural parameters of his native land, he seems to develop little understanding for their internal and external cultural aspects. And thus he adopts a strange behavior. He deliberately endangers his life among the Lilliputians, and remains under a constant fear of being crushed to death among Brobdingnagians. In Laputa, he feels ignored by his hosts and thus hastens to leave and jeopardizes his life. He is swayed away by his irrational love for the Houyhnhnms and falls in love with them. He emerges like a naïve in every subsequent visit. Any seasoned person like him is expected to anticipate the adjustment issues that one can possibly face while living among people of a different culture in a new environment. Perhaps, Gulliver learns nothing from his previous experiences as he exists in the moment he lives. He is least aware of what he does and what he needs to do. His lack of self-knowledge is indicative of his identity crisis. He is disturbed but does not know the cause of his disturbance. Consequently, he is unable to chalk out a strategy for his future. He seems unaware of how his own nature is causing problems for him. Such aspects of his behavior during his stay abroad make him fairly relevant to thousands of travelers who fail to handle culture shock and adopt a strange behavior. Students, professionals, and immigrants if fail to adjust in the host culture may adopt a behavior that is not acceptable to the host society. Some of them may have to return in the mid of their stay as they find it difficult to live among their hosts.

\section{Literature Review}

Most of the earlier and later critics have read Gulliver's character from allegorical perspective. They see him as a mouthpiece of Swift. Sir Charles Firth (1919) and A. E. Case (1958) read Gulliver's Travels as political allegory in which Swift targets his political opponents. Critics like Todd (1991) and Tilton(1959) consider Gulliver to be a real character and not a mouthpiece of Swift. However, modern critics, like Brown (1964) and Tuveson(1964), read it from psychoanalytic perspective. Many of them disapprove of Swift's stance. They believe that he has focused on issues pertaining to anality to uncover human nature. However, such critics target Swift more and provide less information about Gulliver.

\section{Objectives and Approach}

Unlike the previous studies, this paper focuses on how Gulliver wades through the effects of culture shock and how, like him, many travelers in our contemporary world remain unable to manage the problems associated with culture shock. The study shows that Gulliver is not merely a character in a book of literature, but he lives around us. He relates to all those sojourners who go suffer from the effects of culture shock. The study inquires why and how Gulliver suffers from the adverse effects of culture shock, and how he still exists around us. The study endeavors to establish that culture shock was and is a significant factor in determining the behavior people while living among their hosts.

\section{Methodology}

The methodology of this research rests on an intensive analysis of the primary text. It pays careful attention to Gulliver's behavior among his different hosts and how he changes his behavior owing to the repercussions of culture shock. A number of secondary sources have been read and analyzed to show how different critics and researchers observe Gulliver's behavior on different lands.

\section{Discussion and Textual Analysis}

The effects of culture shock transcend all barriers based on race, colour, religion, caste, and nationalities. Majority of the sojourners may confront this problem. In the perspective of culture shock, Gulliver acquires a symbolic relevance to our society in specific and humanity in general. We live among 'Gullivers'. They dwell not only in our immediate surrounding but everywhere. 
Financial constraints force middle class to go abroad. A huge majority among them easily fall a victim to negative impacts of culture shock due to their own complexes. However, many have the ability to cope successfully with such issues which result in their psychic growth. They adapt to the changed environment. Whereas, in case of unsuccessful adaptation, the sojourners have to face multitude of problems. Like Gulliver, not only do they become a source of problems for themselves, but they also for the others.

Our respective cultures shape us. Culture bears a strong impact on whatever we eat and wear, whatever we do, and whatever we think. It not only designs our pattern of thought but also moulds our perspective about others and ourselves. What differentiates us from the people living in other cultures is our pattern of thoughts. Like a computer program, our thought pattern determines our actions and reactions in different situations. It is familiarity with our culture due to which we feel more comfortable in our own native land. Perhaps this is the reason why we feel disturbed while being in a different and new land. And perhaps this is why we confront multitude of problems while being abroad: we are unable to enjoy our stay as a tourist; we cannot study with proper concentration as a student; and we fail to perform with all our potentialities as an employee. We find it difficult to a normal frequency of interaction with the people abroad. Since we weigh and judge everything as per the parameters of our native culture, we suffer both physically and psychologically.

Bochner (2001) is of the view that travelers who go abroad come up with different psychological responses when they are exposed to a new culture. The dichotomy between the native and host culture may take them in different directions. They are in a dilemma about their own identity; they don't know who they are. It is labeled as 'Marginal' response. Recent studies on culture shock repot that students who go abroad remain perturbed to get adjusted in the alien land and with people of a different culture. According to Furham (2001), students suffer from a sense of self isolation and powerlessness which in turn exposes them to psychological complications making their life difficult in a new place. Psychological complexities and 'Marginal' behavior are intertwined in this context.

Swift avoids providing ample details about Gulliver's more than two years long stay as a student in Holland, but since Gulliver had restricted himself to studies during his academic pursuits in Cambridge and London, one may assume that at Leyden too he would do the same. Such restricted attitude implies problem of adapting to the new place. Majority of the students face adjustment issues and develop psychological complexities and thus fail to make adjustment. Perhaps Gulliver is confronted with a similar situation which is why he does not show any psychic development. Like other students, there are reasons to believe that Gulliver might have adopted a 'Marginal' response while being at Leyden. He is unable to develop any friendship or make acquaintance at Leyden. He never provides any details of his stay and acquaintance there. Generally, the experience of living in different cultures results in psychic enlargement which seems impossible for a person like Gulliver who seems to exist at a superficial level.

In most of the cases, middle class people have latent potentialities but they remain unaware of them. Under the effects of culture shock, such problems may aggravate. Being raised in a middle class family, Gulliver is also blind to his potential abilities. His stay among Lilliputians provides a better chance to discover those aspects of his personality which are otherwise unknown to him. However, culture shock seems to have adverse impact on his personality due to which he remains unable to access his latent abilities and make use of them for his own good. In order to please the Lilliputian emperor, he arranges "mock Skirmishes" (Swift, 26) patterned on "the best military Discipline" (p.27). This is the time when Gulliver could use his training of Lilliputians as a card to win his liberty in a decent way but he seems to be unaware of his potentialities. Similarly, he prepares 
"wooden Chamber" (p. 96), closets that looks like a "London Bed-Chamber" (p. 96) and "Canechairs" in England" (p. 118). In spite of such potentialities, he is unable to utilize these for his benefit. He does not have the ability to analyse any situation. He is driven by what the moment demands. Maybe this is the reason that he never tries to deal in furniture business. The rising middle class in eighteen century England could have offered him better prospects to establish his business. But Gulliver seems to do well only when he is forced by circumstances; he is unable to develop understanding for such issues. Consequently, his tiny hosts in Lilliput make use of his abilities without he being aware of it. Price (1963) believes that Gulliver cannot see beyond the physical existence of the things. He is a man of senses and lives only in the outer world. Perhaps this is why, he seeks help from outside and is unable to help himself out of any difficult situation. Thus, instead of trying to liberate himself, he begs to the Emperor "on [his] Knees" (p.18). He adopts an extremely servile and "most submissive Manner" (p. 7) in the Lilliputian court.

It is a common trait of most of the travelers that they are unable to develop understanding of their hosts' thought pattern and internal culture and thus remains unable to follow the conventions of the hosts. Ward et al.(2001) also hold a similar opinion. They contend that some people are flexible in their behavior and easily adapt to the new environment. But some sojourners are rendered helpless and frustrated as they fail to adjust with the new environment. As a result, it is difficult for such sojourners to grasp the thought pattern of their hosts. They are more prone to be swayed away by what they can see and what is visible. They judge the new culture and act as per the requirement of their own native culture. Gulliver acts in a similar way when he starts living among the Brobdingnagians. For him big is strong and small is weak. The enormity of Brobdingnagians' size seems to have overwhelmed his senses. He remains under a constant fear and thus fails to understand the parameters and cues of the internal culture of Brobdingnagians. The manner in which he misjudges the viciousness of tiny Lilliputians, he miscalculates the peaceful nature of Brobdingnagians. While among his latter hosts, he constantly endeavors to appease them. Since his focus is on the external appearance of his hosts, he fails to grasp the cues and signs of their internal culture. Though he stays close to the Emperor while being at Brobdingnag, he is unable to read his mind. After Gulliver joins the court, the Emperor wants to know about his reality. Besides being at home in "Philosophy and particularly Mathematicks"(Swift, 94), the Emperor also has a deep insight in Politics, Law, Government, Justice, War as well human nature. But Gulliver cannot see through his critical and analytical approach. The Emperor is least impressed with what Gulliver says and does. He can see what Gulliver tries to hide about "own dear native Country" (p. 121). The Emperor, despite ruling a nation that lives away from human society, shows great ability to understand the pettiness of human thinking. He is against war and violence. However, for a person like Gulliver, it seems impossible to understand the thought pattern of Emperor's mind.

With increasing interest in travelling abroad, cultural interaction has increased to a large extent due to which sojourners have been faced with problems pertaining to adjustment. Cortes (2003) further adds that disparity in cultural values and patterns of communication bring in temperamental problems in them. This causes not only nostalgic feelings but also adds to mental confusion. Folkman et.al (1985) believe the stress caused by adjustment to an alien culture results in withdrawal which in turn renders the sojourner helpless and dissatisfied. While evaluating stress and coping strategies, they point withdrawal as one of the effects of stress related to facing a new culture. Resorting to withdrawal multiplies the problems of the sojourner; it causes dissatisfaction and adds further complications to the situation confronting the sojourners. Weaver (2001) in his research study shows that the stress of loneliness makes the sojourners hostile and aggressive. He further adds the sojourners then try to avoid those people with whom they cannot adjust. Perhaps this is the reason which makes sojourners regret their going abroad and desires to go back home. They may also react in a more aggressive manner if they are unable to return home. In case they try to control their anger, they are more likely to suffer from depression which makes them feel 
hopeless and helpless. Gulliver is entangled in a similar situation when he is made captive by the Brobdingnagian farmer. Since he is helpless and powerless, Gulliver has no other option but to obey the farmer. He cannot express his anger. In such a precarious situation, Glumdulclitch is his only source of comfort. Though she provides every possible way to make him feel comfortable, he remains in distress. This is perhaps the reason due to which he wants to "devote [his] life to her Majesty's service" (p. 92) when taken to the royal court. However, his misery does not end here; at the royal court, he is constantly under the attacks of the dwarf. The Queen's Dwarf "Mortif[ies]"(p. 99) him the most. Since he is helpless and powerless, Gulliver is not in a position to settle scores with him. The only option he has is to repress his displeasure and anger. This is a tangible reason for him to fall a victim to a severe spell of depression which he does in the concluding pages of his stay at Brobdingnag.

Staying away from one's family in other countries and cities to earn livelihood is not uncommon in this era. However, it creates a sort of emotional vacuum while being away from family. Many people marry secretly; some develop illicit relationships. The ones who are unable to do so may develop psychological issues. In case of Gulliver, the situation is a bit different. He appears to be unconscious of his emotional. Deep inside, he needs someone to be with him to cater for his emotional needs but owing to his extrovert personality, he seems to be least aware of his inner needs. His fondness for Glumdalclitch can easily be understood in this context. He is being looked after by her in the most befitting manner. It is to her that he owes his "preservation in that country" (p. 86). Perhaps this is why Gulliver feels more comfortable in her company. To some extent, she fills the emotional vacuum in Gulliver's life. However, the disparity in their sizes obstructs filling this vacuum. As a consequence, Gulliver remains quite disturbed among his giant hosts.

Giddens(1991) opines that the very existence of sojourner is at risk due to the stress and anxiety related to culture shock. He further says that such a situation may also result in providing inner strength to the sojourner. But in certain cases, it may weaken him and his entire personality. This may result in deterioration of his identity crisis. At Laggnag, Gulliver confronts a similar situation. He presents himself as a seasoned traveler there. Many people see him "out of Curiosity" (p. 204). In fact he has invited problems by behaving in such a manner. He poses to be a person of great eminence and thus is presented to the King. Owing to the etiquettes of the court, he has to "crawl upon [his] Belly, and lick the Floor" (p. 205). He jeopardizes his self-esteem. It is not unmanageable to avoid such a situation simply by keeping a low profile. However, he sees himself bigger and more important than others. His behavior becomes unbecoming of him. Besides being forced to other strange and disgraceful acts, he is made to utter some strange words in praise of the king. Perhaps it may be due to his fear of being insecure that he seems to have compromised his self-respect. This situation finally results in further deterioration of his identity crisis. He presents himself as a "Dutch Merchant" (p. 217). He sets aside all moral principles that he claims to profess. He fails to adapt to his hosts way of life and thus has to leave the place.

N. J. Adler(1991) asserts that many sojourners remain indifferent to various aspect of their native culture. They feel surprised when other people point such aspects. J. S. Adler(1972) thinks on a similar pattern; he is of the view that majority of the people remain oblivious of their own culture, norms, attitudes and beliefs. It is when they are exposed to a new culture that they start realizing those dimensions of their native culture about which they have been unaware of. This provides a better opportunity to know and understand their own cultural norms and values. Weaver(2001) also holds a similar opinion. He believes that culture shock makes us realize how our culture directs and controls our acts and responses. But one cannot ignore the psychological disposition of a sojourner. This factor plays a decisive role in determining the response of a sojourner while going through culture shock. Gulliver's stay in Houyhnhnmland seems quite pertinent in such a context. Gulliver, while among Houyhnhnms, can easily see several aspects of his own culture to which he remains 
oblivious so far. His outlook changes about his native culture. Now he looks at people from an entirely different lens and "in a very different Light" (p. 262).

Limited understanding of a culture, according to Buttaro(2014), causes misunderstood assumptions and judgments. For him, some cultural aspects are universal in nature but there are certain cultural aspects which are peculiar in nature and are limited to a few places. Disparity in the cultural norms between the new and native cultures results in misunderstanding between the sojourners and the hosts. This may add to the problems of the former. Gulliver cannot realize that he is in a different land among different people. This is why, from the very initial days of his arrival in Houyhnhnmland, he judges the inhabitants from the lens of his own cultural norms. He lives in a mist of misunderstanding. Gulliver behaves like a conventional eighteenth century Englishman, he thinks high of himself. He believes he is more civilized than the inhabitants of the place he arrives in. He assumes, he is has arrived in India. He develops repulsion the moment he comes across Yahoos. He looks at the with "Contempt and Aversion" (p. 226). Berry (1994) labels such reaction as 'Separation': a pattern of behavior that makes a person abhors the hosts' way of life and is glued to his native cultural identity. Berry links such behavior to inability of psychological adjustment on part of sojourner. In one of his previous studies, Berry relates such an outlook to psychological maladjustment of the sojourner. Schmidt (1997)relates such behavior to neurosis and psychosis leading to anxiety. It is in this context that one may easily understand Gulliver's antagonistic attitude towards Yahoos. Gulliver behaves more like a racist who sees himself superior to others. Yahoos are "deformed" (p.225) and despicable. Soon after he observes them, he is disgusted by their appearance. To him, they appear more as "ugly Monster" (p.226). He seems to have forgotten the horrifying sight when he first sees Strudbruggs. His memory doesn't support him to recall the "Horror and Disgust" (p.111) which he felt when he got close to the Brobdingnagian maids. Perhaps this is why he claims that he has never come across more "disagreeable an Animal" (p.225) as Yahoos are. He carries along an air of superiority due to which he looks down upon the Yahoos after his arrival in Houyhnhnmland.

Gulliver's interaction with Houyhnhnms exposes some other aspects of his psychological complexities which add to the deterioration of his personality. An obvious transformation in his personality can be seen when he returns to his native land from Houyhnhnmland. He becomes misfit to live among human beings. He is transformed into another being; he is no more that Gulliver who we meet on the first page of Gulliver's Travels. For Weaver(2001), culture shock is like death/rebirth phenomenon. Sojourners during their stay mostly adopt the life style of the new culture. This is not an easy process as the sojourners have to pass through a great deal of emotional and mental disturbance. This is comparable to the way the adolescents step into adulthood. The metaphorical death of the child results into the birth of an adult life. And this is what the sojourners go through during the process of culture shock. In case of Gulliver, it is more a psychological death/rebirth that he experiences during his long stay with Houyhnhnms.

Weaver(2000) is of the opinion that if neurotic aggression of the sojourners is not controlled, it may result in depression. The sojourners are unable to control the problems they are confronted with. They succumb to hopelessness and helplessness as they are unable to identify the real cause of their distress. This naturally results in irrational and unacceptable behavior. This sort of behavior is usually adopted in the mid of culture shock which Weaver labels as Filter stage. The sojourners try to oversimplify the nature of the complex problems they are faced with. They are also prone to twist the real face of the situation they confront among their hosts . At times, the sojourners deny their own culture and thus they over adopt their hosts' culture. In most of the cases, they imitate and adopt the external aspects of the new culture. They may learn the new language and dress like the hosts. They may eat like the hosts eat. However, by doing so the sojourners cannot absorb themselves in the host culture or they may not be given acceptability to become a member of host 
society. The Diaspora from the third world settled in the west mostly comes across such situation. Despite adopting the external aspects of hosts' culture, they are never accepted and are mostly ridiculed by the hosts. Like Gulliver, they see themselves as a part of host culture and look down upon their native people. They adopt the hosts' dress code, their hair style, their accent and use the brands commonly used by their hosts. But they are not able to develop understanding about the internal aspects of their hosts' culture. They Diaspora cannot change their complexion, their skin and their cultural genes. They fail to fit themselves in the hosts' culture as they are unable to inculcate the very essence of their hosts' cultural cues and signs. Like Gulliver, they look at themselves from their own eyes, and never try to see how others look at them. They may develop friendship with the local people there but that does not make them acceptable to the hosts' society.

\section{Findings and Implications}

The way Gulliver suffers reflects how sojourners in general are unhinged by problems pertaining to culture shock. The ones who already have psychological issues are prone to more severe effects of culture shock. Culture shock emerges as a complex phenomenon because it pertains to both culture and psychology. Culture is like a software which controls and chanalizes our behavior and responses. Our culture prevails over us everywhere we go. Be it resolving our issues, our thought pattern, our outlook to life, emotional responses, or our way of interaction with the people around us, every aspect reflects the culture we belong to. Rarely do we come across a person who goes against the prevailing culture norms of his/her society. Our personal and social life is always based on the parameters provided by our culture. Perhaps this is the reason that we feel dis-eased when we live abroad. Displacement from one's culture results in disorientation. A better psychic equilibrium is needed to do away with the problems related to culture shock. Gulliver has remained unable to cope with the complexities involved in cultural adaptation mainly because of his failure to maintain a psychic balance. Perhaps this appears to be the reason behind all his suffering while being among his hosts. In this context, Gulliver's suffering makes one think that in this modern era of globalization, culture shock has gained more relevance since international traveling has become a common norm. And this is why, we can learn a great deal from the experiences that Gulliver has gone through.

\section{Bibliography}

Berry, W. J. (1994). Acculturative Stress. In W. L. Malpass (Ed.), Psychology and Culture (pp. 211215).

Bochner, S. A. Furnham (1986). Culture Shock: Psychological Reactions to Unfamiliar Environments. London and New York: Methuen.

Buttaro, L. (2014). Cultural Competency: The Effects of Culture Shock and Langauge Stress in Health Education. International Journal of Business, Humanities and Technology, 27-34.

C. Ward, S. B. (2001). The Psychology of Culture Shock. London: Routledge.

Case, A. E. (1958). Personal and Political Satire in Gulliver's Travels. In Four Essays Oon Gulliver's Travels (pp. 69-86). Princeton: Princeton University Press.

E., Cortes. D. (2003). Idioms of Distress, Acculturation and Depression: The Puerto Rican Experience. In P. M. K. M. Chuna (Ed.), Acculturation: Advances in Theory, Measurement and Applied Research (pp. 207-222). Washington D. C. : American Psychological Sassociation.

Firth, C. H. (1919-1920). The Political Significance of Gulliver's Travels. British Academy, (pp. 123). London.

Giddens, A. (1991). Modrenity and Self-Identity: Self and Society in the Late Modern Age. Cambridge: Blackwell.

Norman O. Brown(1964), "The Excremental Vision," Swift: A Collection of Critical Essays, ed., Earnest Tuveson (Englewood Cliffs, New Jersey: Prentice Hall), p. 38.

Price, M. (1963). Swift's Rhetorical Art: A Study in Structure and Meaning. London: Yale 
University Press.

S. Folkman, R. S. (1985). If it Changes it Must be a Process: Studies of Emotion and Coping in Three Stages of a College Examination. Journal of Personality and Social Psychology, 150170.

Schmidt, P. G. (1997). Immigrant Mental and Physical Health. Psychology and Developing Societies, 117-131.

Swift, J. (1971). Gulliver's Travels. (P. Turner, Ed.) Oxford: Oxford University Press.

Tilton, J. W. (1959). Gulliver's Travels: As a Work of Art. Bucknell Review, 246-259.

Todd, D. (1992). The Hairy Maid at the Harpsichord: Some Speculations on the Meaning of Gulliver's Travels. Texas Studies in Literature and Language, 238-283.

Weaver, G. (1994). Understanding and Coping with Cross-Cultural Adjustment Stress. In C. C. Relations, \& G. Weaver (Ed.). CA: Simon and Schuster.

Weaver, G. (2014). Intercultural Relations: Communication, Identity, and Conflict. Boston: Pearson. 